\title{
Penyuluhan Pemanfaatan Tanaman Obat Peningkat Sistem Imun Untuk Pencegahan dan Penanggulangan Penyakit COVID-19 di Masyarakat
}

\author{
Counseling on The Use of Immune System Enhancing Medicinal Plants For The \\ Prevention and Control of COVID-19 in The Community
}

\author{
Arista Wahyu Ningsih* \\ Prodi S1 Farmasi STIKES RS Anwar Medika Krian Jawa Timur \\ email : ariessmkkes@gmail.com
}

\begin{abstract}
Abstrak
Pemerintah saat ini sedang berusaha meningkatkan motivasi dan kepedulian masyarakat terhadap kesehatannya dalam rangka pencegahan dan penanggulangan penyakit Covid-19. Globalisasi berperan dalam memfasilitasi terjadinya pandemic virus Covid-19, dimana globalisasi menjadi jalan koneksi antar Negara terbuka bebas. Covid-19 merupakan masalah kesehatan masyarakat di seluruh dunia. Melalui program pengabdian masyarakat STIKES RS Anwar Medika dosen STIKES RS Anwar Medika melakukan penyuluhan tanaman obat peningkat system imun tubuh. Program penyuluhan tersebut bertujuan untuk memberikan gambaran akan pentingnya mengkonsumsi herbal peningkat system imun tubuh dalam rangka pencegahan penyakit Covid-19. Dari hasil penyuluhan yang dilakukan kepada masyarakat evaluasi awal pengetahuan menunjukkan $61 \%$ masyarakat memahami tentang herbal imunodulator untuk pencegahan Covid-19. Setelah dilakukan penyuluhan kepada masyarakat, dilakukan evaluasi akhir pengetahuan. Hasilnya menunjukkan bahwa 84\% masyarakat memahami tentang herbal imunodulator. Dari hasil pretes dan postes terdapat selisih 23\%, menunjukkan bahwa penyuluhan tentang herbal imunodulator yang dipaparkan oleh pemateri menghasilkan kenaikan pemahaman peserta sebesar $23 \%$.
\end{abstract}

Kata kunci: Penyuluhan, Herbal Imunodulator, Covid-19.

\begin{abstract}
The government is currently trying to increase public motivation and concern for their health in the context of preventing and overcoming the Covid-19 disease. Globalization plays a role in facilitating the Covid-19 virus pandemic, where globalization is a way of connection between countries that is open freely. Covid-19 is a public health problem around the world. Through the community service program, STIKES Anwar Medika Hospital, STIKES lecturers at Anwar Medika Hospital provide counseling on medicinal plants to enhance the body's immune system. This extension program aims to provide an overview of the importance of consuming herbs to boost the body's immune system in order to prevent Covid-19 disease. From the results of counseling conducted to the community, the initial evaluation of knowledge shows that $61 \%$ of the public understands about herbal immunodulators for the prevention of Covid-19. After outreach to the community, a final evaluation of knowledge is carried out. The results showed that $84 \%$ of the public understood immunodulator herbs. From the results of the pretest and posttest there was a difference of $23 \%$, indicating that counseling about herbal immunodulators presented by the speakers resulted in an increase in the participants' understanding by $23 \%$.
\end{abstract}

Key words: Counseling, Herbal Immunodulator, Covid-19.

\section{PENDAHULUAN}

covid-19 merupakan masalah kesehatan masyarakat di seluruh dunia. Covid-19 membuat kacau dan cemas lebih dari 200 negara karena sudah terjangkit oleh wabah virus Covid-19. Globalisasi berperan dalam memfasilitasi terjadinya pandemic virus Covid-19, dimana globalisasi menjadi jalan koneksi antar Negara terbuka bebas. Kemudahan transportasi adalah salah satu keuntungan dari globalisasi, dimana kemudahan transportasi tersebut menjadi sarana mobilitas antar Negara dan benua. 
Wabah covid-19 ini menyebar ke seluruh Negara dan benua melalui mobolitas manusia dimana kemunculannya sangat cepat karena kemudahan mobilitas manusia (Ansori \& Hubei, 2020).

Covid-19 saat ini telah menyebar ke Indonesia, sejak presiden Joko Widodo mengumumkan langsung pada tanggal 2 Maret 2020. Menurut Satgas Penanganan Covid-19, Pada tanggal 27 Agustus 2020 Indonesia mengalami kasus posisit covid-19 sebesar 162.884, kasus pasien sembuh sebesar 118.575 dan kasus pasien covid-19 meninggal sebesar 7.064. Indonesia saat ini menjadi salah satu negara di dunia yang terpapar oleh virus COVID-19. Angka kasus Covid-19 saat ini kurvanya belum mengalami penurunan yang baik.

Wabah Covid-19 ini membuat Indonesia menjadi resah karena jenis virus ini adalah virus baru dan belum ditemukan obatnya. Berapa Negara di dunia melakukan berbagai macam penelitian untuk menemukan obat dan vaksin untuk pencegahan dan penyembuhan penyakit Covid-19. Banyak pihak yang tidak mengetahui cara penanggulangan virus ini dan banyak juga yang mengabaikan virus ini karena tidak percaya dengan virus ini. Salah satu penanggulangan virus Covid-19 ini, pemerintah menerbitkan protocol kesehatan. Kementrian kesehatan memandu secara terpusat pelaksanaan protocol kesehatan(Mahfudah \& Situasi, 2020).

Pemerintah Indonesia sangat berupaya dalam pencarian obat untuk melawan virus Covid-19. Upaya yang dilakukan itu dari berbagai aspek seperti studi etnobotani, etnofarmasi, etnofarmakologi yang dilanjutkan pengujian secara in vitro. Beberapa tanaman obat memiliki senyawa kimia yang mampu meningkatkan aktivitas imun. Sistem imun adalah mekanisme tubuh yang digunakan untuk perlindungan dan pertahanan tubuh dari serangan benda asing seperti virus Covid-19. Banyak tanaman obat Indonesia memiliki aktivitas sebagai imunodulator antara lain jahe, mengkudu, meniran, dan sambiloto(Suhirman et al., 1985).
Pengabdian kepada masyarakat adalah salah satu upaya kinerja dosen dalam pengembangan ilmu pengetahuan. Dosen ditntut dalam peran dosen yang tertian dalam Tri Dharma Perguruan Tinggi yaitu pembelajaran, penelitian dan pengabdian masyarakat. Pengabdian masyarakat akan membantu dosen dalam penyelesaian masalah wabah Covid-19 dengan cara meningkatkan pengetahuan masyarakat dalam penggunaaan tanaman obat imunodulator sebagai upaya pencegahan virus Covid-19.

Tujuan dari pengabdian masyarakat ini adalah memberikan wawasan dan informasi, meningkatkan pengetahuan yang baik dan benar tentang cara penggunaan tanaman obat (herbal) yang dapat membantu tubuh dalam melawan virus Covid-19. Dengan adanya latarbelakang tersebut perlu dilakukannya kegiatan pengabdian masyarakat berupa penyuluhan pemanfaatan tanaman obat peningkat system imun untuk pencegahan dan penanggulangan penyakit Covid-19 dalam masyarakat.

\section{SOLUSI/TEKNOLOGI}

Penyuluhan ini dilakukan kepada masyarakat pada tanggal 9 Agustus 2020. Penyuluhan ini dilakukan dengan metode webinar karena kondisi wabah virus Covid19 yang menekankan tidak boleh melakukan pertemuan dalam jumlah banyak. Tim pengabdian kepada masyarakat adalah dosen prodi Farmasi program sarjana. Persiapan penyuluhan ini melibatkan mahasiswa Farmasi program sarjana. Metode yang digunakan dalam penyuluhuan ini adalah dengan cara presentasi dan melakukan pre test dan pos test setelah pemaparan dari pemateri.

Pelaksanaan penyuluhan tersebut dilakukan dengan beberapa tahapan yaitu :

1. Proses perijinan pengabdian kepada masyarakat dari LPPM Stikes RS Anwar Medika

2. Penyusunan jadwal penyuluhan yang disesuaikan dengan kegiatan 
masyarakat, kegiatan ini dilakuan selama 1 hari.

3. Penyuluhan diawali dengan penyajian materi tentang pengertian obat dan virus Covid-19, pengenalan macammacam tanaman obat yang berfungsi sebagai imunodulator, cara pembuatan minuman imudulator dari tanaman obat. Sebelum dilaksanakan penyuluhan, tim pengabdian masyarakat di bantu oleh peserta/warga mempersiapkan peralatan dan bahan yang dibutuhkan dalam penyuluhan ini.

4. Demonstrasi untuk pengecekan kolesterol darah secara langsung menggunakan alat cek kolesterol darah dengan merk Easy Touch.

5. Dilakukan evaluasi terhadap peserta penyuluhan setelah penyajian materi.

Setelah data terkumpul dilakukan analisis data untuk menarik kesimpulan. Proses analisis data tersebut dilakukan dengan beberapa tahapan yaitu :

1. Editing

Proses editing merupakan proses pemeriksaan data dengan melihat kelengkapan hasil pengumpulan data. Data-data yang melalui proses editing antara lain kelengkapan data, Jawaban atau tulisan masing-masing pernyataan cukup jelas atau terbaca, Jawaban yang relevan dengan pertanyaan.

2. Coding

Proses coding meliputi pemberian kode atau nilai pada hasil kuisioner yang dimaksudkan untuk mempermudah dalam pengolahan dan proses selanjutnya melalui tindakan pengklasifikasikan data.

3. Entry Data

Data kuisioner yang telah melalui proses coding akan dimasukkan pada proses entry data yang selanjutnya akan diolah.

4. Teknik Pengolahan Data

Data yang diperoleh dianalisa secara deskriptif kuantitaif dengan melihat hasil post test mengenai perbandingan kepahaman responden terhadap pengetahuan herbal imunodulator dalam pencegahan dan penanggulangan penyakit Covid-19. Hasil yang diperoleh dibuat rata rata, kemudian hasilnya digunakan untuk menarik kesimpulan.

\section{HASIL DAN DISKUSI}

Kegiatan pengabdian masyarakat dilaksanakan oleh dosen Stikes RS Anwar Medika bekerja sama dengan mahasiswa Farmasi program sarjana.Sebelum melakukan penyuluhan, dosen, mahasiswa dan peserta bersama mempersiapkan alat dan bahan yang akan digunakan dalam penyuluhan ini. Kegiatan pengabdian masyarakat tentang penyuluhan pemanfaatan tanaman obat peningkat sistem imun untuk pencegahan dan penanggulangan penyakit Covid-19 di masyarakat. Dalam penyuluhan diawali dengan penjelasan kasus Covid-19 di dunia dan Indonesia, penjelasana Covid-19 dan cara penyebarannya, definisi sistem imun, definisi herbal imunodulator, macammacam herbal peningkat sistem imun, contoh sediaan jamu peningkat sistem imun, dan cara pengolahan atau pembuatan jamu.

Melalui penjelasan ini diharapkan masyarakat mengetahui bahwa Virus COVID-19 dapat menyerang siapapun tanpa mempedulikan batas kelas sosial, suku, dan agama, namun masyarakat kelas bawah merupakan kelompok yang paling rentan dan beresiko. Cepat atau lambat, jika tidak ditangani dengan tepat dan efisien, virus ini akan menyasar secara masif masyarakat kelas bawah Indonesia yang merupakan mayoritas. Masyarakat kelas bawah lebih rentan karena tidak memiliki ketahanan sosial yang lebih baik. Masyarakat kelas bawah juga yang akan merasakan dampak terbesar ditambah jumlahnya yang dominan di negara-negara berkembang seperti Indonesia.

Penjelasan kemudian dilanjutkan mengenai macam - macam tanaman obat peningkat sistem imun antara lain sambiloto, brotowali, pegagan, bawang putih, meniran 
dan jinten hitam. Pada penyuluhan tersebut dijelaskan bagaimana tanaman obat tersebut dapat meningkatkan sistem imun tubuh dan membantu dalam pencegahan wabah Covid19. Herbal imunodulator tersebut akan memperbaiki system imun dengan cara menstimulasi atau menekan reaksi imun yang abnormal. Efek herbal imuodulator tersebut bergantung pada proses pengolahannnya, oleh karena itu pada penyuluhan ini juga djelaskan cara pengolahannya.

Pada awal penyuluhan dalam kegiatan ini dilakukan evaluasi awal pengetahuan terlebih dahulu berupa pretes. Tujuan dari evaluasi awal pengetahuan adalah untuk skrining/pemetaan awal pengetahuan masyarakat. Dari hasil evaluasi awal pengetahuan menunjukkan $61 \%$ masyarakat memahami tentang herbal imunodulator untuk pencegahan Covid-19. Pada akhir penyuluhan juga dilakukan evaluasi akhir pengetahuan berupa postes. Peserta diberikan kembali kuesioner dengan pertanyaan yang sama seperti kuesioner pada observasi awal. Postes tersebut bertujuan untuk mengkonfirmasi dan mengevaluasi apakah materi yang diberikan sudah dapat meningkatkan pengetahuan dan pemahaman peserta. Hasilnya menunjukkan bahwa $84 \%$ masyarakat memahami tentang herbal imunodulator. Dari hasil pretes dan postes terdapat selisih $23 \%$, menunjukkan bahwa penyuluhan tentang herbal imunodulator yang dipaparkan oleh pemateri menghasilkan kenaikan pemahaman peserta sebesar $23 \%$.
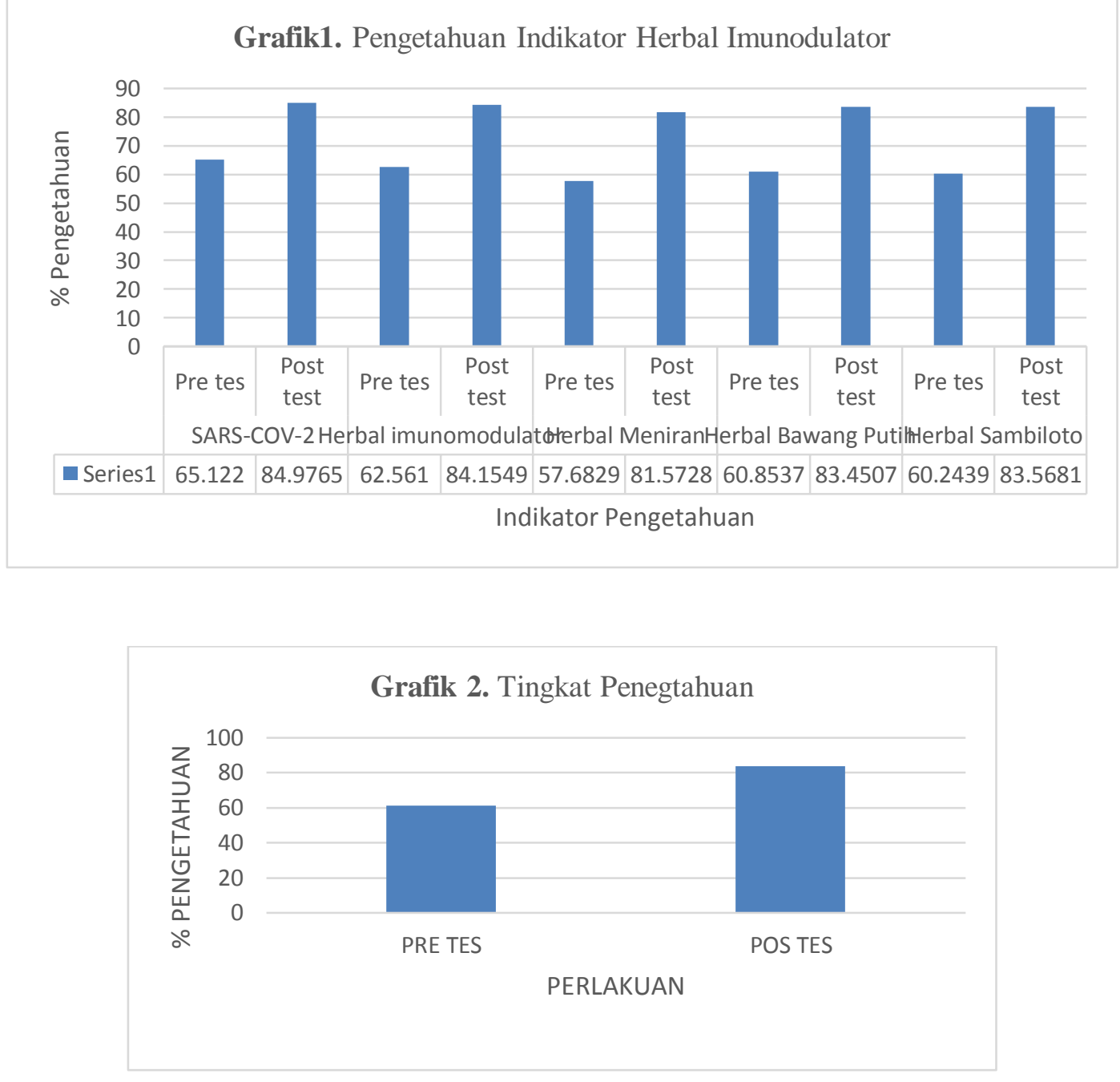
Penyuluhan ini dilakukan sebagai upaya untuk membantu pemerintah dalam menurunkan angka kejadian Covid-19 yang terus melonjak kasusnya. Kondisi sebelum penyuluhan adalah masyarakat semua lapisan belum memahami bahwa tanaman obat Indonesia atau herbal Indonesia banyak yang bisa dimanfaatkan untuk membantu meningkatkan imunitas tubuh. Kondisi setelah penyuluhan adalah masyarakat mulai memahami bahwa tanaman obat Indonesia bisa digunakan untuk meningkatkan system imunitas tubuh. Dengan rutin mengkonsumsi herbal imunodulator dapat membantu tubuh dalam mencegah virus Covid-19 masuk ke dalam tubuh. Peningkatan daya tahan tubuh akan mengurangi virus Covid-19 masuk ke dalam tubuh dan membantu menurunkan angka kejadian Covid-19.

\section{KESIMPULAN}

Penyuluhan pemanfaatan tanaman obat peningkat imunitas dapat meningkatkan pengetahuan dan pemahaman masyarakat sehingga dapat membantu pemerintah dalam menurunkan angka kejadian Covid-19. Saran, Penyuluhan kesehatan secara berkelanjutan harus tetap dilakukan agar kualitas hidup masyarakat terkait kesehatan dapat ditingkatkan.

\section{UCAPAN TERIMA KASIH}

Terima kasih kepada STIKES RS Anwar Medika yang telah mendukung kegiaatan ini dengan lancar.

\section{PUSTAKA}

Ansori, M. H., \& Hubei, P. (2020). Wabah COVID-19 dan Kelas Sosial di Indonesia. 14.

Mahfudah, U., \& Situasi, A. A. (2020). EDUKASI TENTANG BAHAYA PENULARAN COVID-19 PADA APARAT. 2.

Suhirman, S., Penelitian, B., Obat, T., Besar, B., \& Pascapanen, P. (1985). IMUNOMODULATOR. 121-133. 